\title{
Community Participation as a Constitutional Awareness of Democracy Development in Digital Era
}

\author{
Anna Triningsih ${ }^{1 \mathrm{a}}$, Oly Viana Agustine ${ }^{2 \mathrm{a}}$ \\ ${ }^{1}$ Research Center at The Constitutional Court of The Republic Indonesia, Jakarta, Indonesia \\ a mkri_annatriningsih@yahoo.com, bolyviana@mahkamahkonstitusi.go.id
}

\begin{abstract}
Indonesia is one of the constitutional democratic countries that guarantees the protection of every citizen to express opinions, association and assemble. Freedom and openness are important means of creating public participation in the development of democracy in Indonesia. Community participation is also a form of high awareness of the rights of citizens guaranteed by the constitution. In the digital era, community participation in developing democracy is much easier. With their gadgets owned, everyone can participate in developing democracy. However, it is no doubt that the ease provided by the gadget makes people unwise in using it to give or receive hoax news. Therefore, it becomes important for everyone to be able to use the gadget to give or receive factual information in order to be synergistic with the development of democracy. This study will discuss how the community participation as a conscious form of the constitution in the development of democracy in the digital era. The results of this study show that they need a wise attitude to review information obtained or owned to be shared to the public through digital gadgets. Reviewing information will be an important point in the development of democracy. Having the truth that information received or submitted is also as a form of guarantee of freedom of opinion in accordance with the constitution.
\end{abstract}

Keywords—democracy in the digital era, community participation, and conscious awareness of the constitution.

\section{INTRODUCTION}

Democracy is one of the hallmarks of a country that embraces the rule of law. Democracy contains values as reference to organize the life of a nation and a good state. The development of democracy cannot be separated from community participation. Community has an important role in every development of democracy. Where the community is not only the object of democracy but also the subject of democracy. Therefore, democracy running in a country depends on the active role of the community in implementing it. The good democratic system is the power of government coming from the people, where theoretically, the opportunity for the implementation of political participation and citizen participation from all aspects of life is wide open. Democracy is the way to open the door for everyone to have the same position before the law and to protect the human rights that everyone has.

In addition, through democracy, the community can exercise social control over the implementation of government because the position of society is as the holder of the highest sovereignty. Democracy and the rule of law are two concepts of power mechanism in running the wheels of state government. Democracy provides the basis and mechanism of power based on the principle of equality of human beings. At the practical level, the principle of democracy or the sovereignty of the people can ensure the community participation in the decision-making process.Therefore, every legislation applied and enforced truly reflects the senseof community justice.
The constitutional participation of citizens as conscious form is constituted in various ways, namely: a) recognizing and respecting the basic rights of others; b) complying with applicable regulations, such as traffic rules, schools, etc.; c) not making judgement on own authority; d) maintaining a balance between rights and obligations; e) openness and ethics in the face of a problem; f) developing a conscious and rational attitude; g) establishing unity through various activities; h) implementing elections in a transparent, honest, fair and free manner, and in accordance with applicable regulations; i) conducting decision-making by deliberation or voting, instead of money politics, bribery, collusion, and intimidation; j) implementing peaceful demonstrations or actions instead of violence, infiltration or revolution; k) paying taxes on time; 1) conducting state defense in accordance with ability, rights, and obligations and $\mathrm{m}$ ) providing criticism or advice to the government through representatives of the people.

The main problem after the revolving reforms is the absence of freedom with no direction as the basis of democracy. Whereas, the implementation should be limited by the freedom of others. This is called and is known by the principle of rights and obligations. In this case, the rights of others that must be respected and our obligation to adhere to the true democratic system. Proclaiming independence through a long struggle and suffering many victims, the word democracy has an important meaning because it is one of the cornerstones of the opponent's independence that has been achieved. In the contrary, the independence that has been achieved must be filled with a democratic system based on justice. Thus, democracy will be much more 
meaningful because it was the fulfillment of the values of human rights to freedom of expression with all the positive instead of the anarchic freedom. Therefore, the stage is right and good democracy should be put forward that will be encountered in a community lives in the atmosphere of a prosperous corridor applicable law.

In the practice, democracy involving community participation as a conscious form of the constitution has obstacles and challenges in the presence of the digital age. The convenience offered by digitizing information makes the source of information unstoppable. Therefore, public participation in the development of democracy in synergy and conscious harmony with the consciousness will need policy in managing information.

\section{RESEARCH METHOD}

Normative law research method is used in this study. According to Sunaryati Hartono, the study of normative law can look for legal principles, legal theory and the formation of new legal principles [14]. Meanwhile, according to Bagir Manan, normative research is a study of existing legal principles [15]. After the data collected and perceived, the next step is to process and analyze the data. Data analysis technique used in this study is a qualitative analysis technique.

\section{RESULT AND DISCUSSION}

\section{A. Indonesia as A State of Constitutional Democracy}

The State of Indonesia is a state of law (rechtsstaat), as set forth in Article 1 paragraph (3) of the 1945 Constitution of the Republic of Indonesia. It indicates that the implementation of state administration in Indonesia is based on the applicable law. The Constitution regulates the Indonesian state administration aspects of the distribution of state power, the administration of state power to the realization of the goals and ideals of the state.Indonesia is a constitutional State. It means that the implementation of the Indonesian constitutional law is based on the Constitution as the Basic Law of the State (staats-grundnormgesetz). The Constitution as the main law and the result of the representation of the will of all the people must be carried out seriously in every aspect of the life of the nation and the state. Therefore, the principle that arises is that every act, regulation, and/or rule of all authority delegated by the constitution must not be contrast to the constitutional rights of the citizen and the constitution itself. In other words, the constitution should take precedence, and the intention or will of the people must be more important than their representatives.

In line with the opinion of A.A.HStruycken cited by Sri Soemantri, it is stated that the Constitution as a written Constitution is a formal document containing [1]:

1. The results of the political struggle of the nation in the past.

2. The highest levels of national development of the nation.

3. The views of national figures who want to be realized, both for the present and the future.
4. A desire, with which the development of national governance of the nation to be led.

Sidney Hook defines democracy as a form of government in which important government decisions or policy directions behind decisions are directly based on decisions of a majority given freely from the adult population [2]. A comprehensive criterion of democracy was also proposed by Gwendolen M. Carter, John H. Herz, and Henry B. Mayo. Carter and Herz conceptualized democracy as a government characterized by and exercised through principles [3]: 1) restrictions on government action to provide protection for individuals and groups by making regular, orderly and peaceful leadership changes, and through the tools of popular effective representation; 2) tolerance of opposing opinions; 3 ) equality before the law which is manifested by being subject to the rule of law without distinction of political position; 4) the existence of free elections in the presence of an effective representative model; 5) granting freedom of participation and opposition to political parties, civic organizations, communities, and individuals as well as public opinion infrastructures such as the press and mass media; 6) respect for the right of the people to express their views no matter how wrong and unpopular the view is, and 7) the development of respect for the rights of minorities and individuals by prioritizing the use of persuasive and discussion rather than coercive and repressive means.

\section{B. Community Participation as A Constitutional Consequence}

\section{Guarantees of Freedom within the Constitution}

JimlyAsshiddiqie argues that one of the essential elements in the rule of law is the fulfillment of basic rights [4]. His opinion is reinforced by Friedrich Julius Stahl stating thatone of the elements possessed by the state law is the fulfillment of basic rights/fundamental rights or human rights.

Indonesia as a State of law has implemented the protection and respect for the rights of citizens. Whereas, the protection and respect of human rights are applied to the constitution or the 1945 Constitution. It can be concluded that Indonesia's understanding of human rights is a dignity in human beings as a gift given by God Almighty. Therefore, the State guarantees it in the legitimacy of human rights into the 1945 Constitution which is called the constitutional rights of citizens. In establishing the legal state of Indonesia, the founding fathers of the country have listed human rights and citizens' rights on the 1945 Constitution. The guarantee of human rights protection is considered an absolute requirementin every country. Even in its development, these human rights guarantees are also required to be expressly stated in the constitution of a constitutional democracy.

The provisions on human rights and the rights of the citizens has been increased significantly in the 1945 Constitution after the amendment. Included in this context, since the beginning, the 1945 Constitution has regulated human rights and civil rights in the form of guarantee of the independence of every citizen to embrace religion and to worship based on their religion and belief. 
The Indonesian Constitution, the 1945 Constitution, explains that Indonesia is a democracy. The President in carrying out his/her duties must be accountable to the People's Legislative Assembly and the People's Consultative Assembly as a representative of the people. Therefore, the people are the holder of supreme authority through a system of representation through the government.

Post-reform defines Indonesia is a nation of democracy and a state of law that protects every citizen in any form of freedom of expression, convey the idea both orally and in writing.It is protected by laws and regulations in Indonesia both within the body of the 1945 Constitution in Article 28, set out clearly in Law No. 12 of 2005 on the guarantee of civil and political rights, in which the right points that should be protected by the state regarding the right to argue, the right to association, the right to vote and the election, equal rights before the law and government, and right to get justice.

In 1999 and 2004, for the first time, the Indonesia held presidential elections. And this is a new history in democratic life in Indonesia and the development of democracy and freedom of speech for citizens who continue to the process in line with the dynamics of the Indonesian people and the existing state system.

The concept of democracy or people's government applied in Indonesia is based on three things, namely:

1. The values of the philosophy of Pancasila or the government itself, from, by and for the people based on the pillars of Pancasila;

2. Transformation of values in the governance system;

3. It is a consequence and commitment to the values of Pancasila and the 1945 Constitution.

The basic idea of a democratic government in the Indonesian government is the recognition of human rights, the essence of human beings, i.e., basically, citizens have the same dignity in the social relations of citizens. For the sake of ensuring the establishment of the democratic system and the upholding of justice and human rights, the existence of a state law is absolute. The new constitution is ideal if there is a guarantee of freedom of human rights, the formulation and limitation of government power, and strong control over the exercise of government power itself [5].

\section{Community Participation as Conscious Form of the Constitution}

The word participation comes from English which means taking part, participate. While the word participation comes from the participatory word which means to include. Along with that definition, participation can be interpreted as taking partor participating [6]. In the Indonesian dictionary, the definition of participation is related to taking partin an activity or participating in an activity. Therefore, it can be interpreted that participation is a party is doing an activity.

The existence of parliament, parties, and press freedom as well as election periods are the opportunities and possibilities provided by political democracy in order to awaken the people and lead to the struggle for their rights. The awareness of the people is drawn to the effort to give the understanding that the right situation for this social problem lies in the attempt to change the circumstances that are detrimental to them.

The independence and participation of the people who are actively involved in social media are the embodiment of the constitutionally conscious form in the development of democracy in the digital era. With mutual respect for the opinions of others is a form of constitutional stance in which every citizen is given the freedom to express opinions in accordance with his nature. Freedom is not interpreted freely, however, the freedom that can be accountable both to God Almighty, fellow human beings and the nation and state.

It is no doubt that in the digital world, there will be the contention of opinion. Submission of criticism must be clear instead of just an argument without factual information. The criticism given is an attempt to straighten the perverted conversation.

Before the digital era, public participation could be direct protests conducted in the field. Meanwhile, in the digital era, people can express opinions simply by through their gadgets. The type of delivery is also diverse, whether done individually in the form of opinions or articles or groups of people with large numbers such as petitions.

\section{Development of Democracy in the Digital Era \\ 1. Easy Access to Information in the Digital Age}

The development of technology in the direction of all-digital grow more rapidly. In this digital age, people generally have a new lifestyle that cannot be separated from electronic devices. Technology has become a tool that can help most human needs. Technology has been used by people to make them easier to do any task and work. The important role of technology is what brings human civilization into the digital age. The digital era has brought many good changes as a positive impact that can be used as well as possible. But at the same time, the digital era also brings many negative impacts. It becomes a new challenge in human life in this digital age. Challenges in the digital age have also entered into areas such as politics, economics, socio-culture, defense, security, and information technology itself [7].

The digital era also makes the privacy of people seem to disappear. Personal data recorded in the brain of the computer make the internet citizens easy to track, both in terms of surfing hobby. The digital era is neither a ready or a problem nor an option but a consequence. Technology will continue to move like the ocean currents that continue to run in the midst of human life. Then, there is no other choice but to master and control the technology properly and correctly in order to give maximum benefits. Today's increasingly sophisticated digital technology has led to major world changes. People have been facilitated in accessing information through many ways, and can enjoy the facilities of digital technology freely, however, negative impacts also appear as threatening. Crime is easy to facilitate, online games can damage the young generation, pornography, and copyright infringement are easy to do, etc. There has been a digital revolution since the 1980s with changes in mechanical and analog technology to digital 
technology and continues to grow to this day. The development of this technology became massive after the invention of personal computer system is designed and organized automatically to receive and store data input, process, and produce output under the control of electronic instructions stored in memory that can manipulate data quickly and precisely. The birth of social networking site which is a web-based service allows users to create profiles, see the list of available users and invite or accept friends to join the site. The relationship between mobile devices and Internet web pages through "social networking" has become the standard in digital communications. The digital revolution is the ability to easily move digital information between media, and to access or distribute it remotely [8].

\section{Development of Democracy}

As a democracy, freedom of expression does not have to be free to express opinions but must be responsible and ethical. Determining the ethical value parameters in ideal arguments is very difficult. Any attempt to determine ethical limits will argue as castration opinion. Even, new laws, such as the Electronic Information and Transaction Act (UU ITE) created by jurists and democratic warriors, are considered to emasculate freedom of expression. The ethics of such opinion need not necessarily correspond to ethics. However, the opinion must be in accordance with the actual facts without having to justify the fact that is still unclear. The freedom of expression cannot reverse the facts that exist. If this happens, it will be a libel and defamation. If ethics argues only violate customary ethics, culture and politeness are not the problem because the sanctions are just a social sanction [9].

Freedom of opinion or expression of opinion is the right for every citizen guaranteed by the 1945 Constitution.Even, the right of freedom of expression occupies the highest position in the principles of democracy and liberalization.There is still a corridor or legal restrictions. There is also a distribution through the representative agencies in the House of Representative or Regional House of Representative and the right to freedom of expression should not violate the rights of others because basically every citizen has the right to freedom of opinion atthe same position [10].

In exercising the right to express an opinion, it must hold the principle of free and responsible. Free means that any ideas, thoughts or opinions can be freely expressed without any pressure from anyone. While responsible means that ideas, thoughts or opinions should be based on common sense, good faith and applied norms.

Freedom of expression must be carried out in a responsible manner, in accordance with the provisions of Article 28 of the 1945 Constitution and the principles of international law as set forth in Article 29 of the Universal Declaration of Human Rights of the 1949 Decree which is applicable universally in the world, including Indonesia. Based on Law no. 9/1998 on freedom of expression in public, there are five principles which form the basis of freedom of responsibility and act to convey public opinion, namely [11]:
1. The principle of a balance between rights and obligations

2. The principle of deliberation and consensus

3. The principle of certainty of rights and justice

4. The principle of proportionality

5. The principle of consensus

Citizens expressing a public opinion are obliged and responsible for [12]:

1. Respect the rights and freedoms of others

2. Respect for commonly recognized moral rules

3. Comply with applicable laws and regulations

4. Maintain security and public order

5. Maintain the national unity

There are several things that must be considered in expressing opinions freely and responsibly [13]:

a. The opinions and the arguments expressed are strong and reasonable rather thanarbitrary.

b. Opinions should represent the interests of the people to benefit the common life

c. Opinions are expressed within the framework of the applicable rules to not violate the rights

d. People who have opinions should be open and ready to accept criticism and advice from others

e. Submission of opinion should be based on a common desire and goodness to develop the values of justice and democracy. However, citizens freely express opinions as long as it does not contradict the philosophy of Pancasila, the 1945 Constitution, and the purpose of the Republic of Indonesia.

Freedom of expression is a human right, because the nature of each human being has differences, including the level of knowledge/education, mindset, the perspective of a problem. To guarantee every citizen in exercising his/her rights, the community/state shall make the rules so that in exercising that right does not clash with the rights of others. In exercising their rights and freedoms, each person shall be subject to the restrictions laid down by law with the sole intent of ensuring the recognition and respect of the rights and freedoms of others and to satisfy fair demands in accordance with moral judgments, religious values, security and public order in a democratic society [14].

\section{Challenge sin the Digital Era}

The digital era does not only offer great opportunities and benefits for the public and business interests, but also provides challenges to all areas of life to improve the quality and efficiency of life. The use of various technologies is very easy life, but the digital lifestyle will increasingly depend on the use of mobile phones and computers. Every use of technology requires it to control. The rapid development of technology to penetrate the entire social life of society, it turns out not only changed the social life, society culture but also political life. The sophistication of technology developed by human being is really utilized by politicians who want to gain sympathy, and empathy from the wider community. To increase electability and popularity, they can use digital facilities such as the smartphones with the features/advanced applications that connect directly to social networks that are able to connect between individuals 
with one another, between one group with another group and even countries that provide great impact in modern politics.

Electronic mechanisms have also changed activity in elections such as internet-based campaigns, websites, email, and podcasts. It is a facility for candidates and political parties as a quick and cheap means of sending messages to the audience, enabling them to recruit campaign volunteers and raise campaign funds.The uses of digital media, Smartphones, linked to social networks are very effective especially in reaching out to young people, who are often the most difficult segments of society to engage through conventional strategies. The other side of the new faces and political power in the digital age is also to be used as a systematic propagation tool ideologically to seek support as well as institutional ideological values, and as a tool for propaganda machines, how politicians seek to maintain power by displaying a good image and hiding a negative image to get support from the public [15].

\section{CONCLUSION}

Democracy is a mechanism of social control over the implementation of government policies that involve the community as the holder of the highest sovereignty. Democracy opens the space for public participation in running the wheels of state government. The implementation of democracy by involving community participation is a conscious form of the constitution. Facing the digital era, there are various challenges and opportunities that can be used to increase community participation in the development of democracy. The facilities offered must be balanced with policies in managing existing content. The community can play an active role in criticizing government policies but by first managing the information so that no false news is created. Thus, the active role of the community wisely will foster harmonization and synergy between community participation in the development of democracy in the digital era.

\section{ACKNOWLEDGEMENT}

The authors would like to express their gratitude to all parties in The Constitutional Court of the Republic of Indonesia and the ICILSUNNES committee who have assisted in the holding of the conference.

\section{REFERENCES}

[1] Sri Soemanteri, "Procedure and System of Constitutional Amendment", Prosedur dan SistemPerubahanKonstitusi, Disertasi, Alumni, Bandung,1987, p. 2.
[2] Sidney Hook dalam Nakamura dan Samallowood, The Polities of Policy Implementation, st. Martin's Press, New York, 1980, p. 67

[3] Gwendolen M. Carter dan John Herz, "The Role of Government in Today's Society", PerananPemerintahdalam Masyarakat Masa Kini, dalam Miriam Budiardjo, "State Issues", MasalahKenegaraan, Gramedia, Jakarta, 1982, p. $86-87$.

[4] JimlyAsshiddiqie, Introduction to the Constitutional Law Science, cet.ke-2 (Jakarta: Rajawali Pres, 2010, p. 343

[5] Arif Zulkifli dkk (Seri Buku Tempo), YAP THIAM HIEN, "100 Years of the Swordsman of Justice", 100 Tahun Sang PendekarKeadilan, PT. Gramedia, Jakarta, 2013, p. 52-53.

[6] HeriKusmanto, "Community Participation in Political Democracy", Partisipasi Masyarakat dalamDemokrasiPolitik, JurnalIlmuPemerintahan dan SosialPolitik UMA, Volume 2 No1, Tahun 2014, p. 77-89.

[7] Wawan Setiawan, "The Digital Age and Its Challenges", Era Digital dan Tantangannya, Seminar Nasional Pendidikan 2017, diakses pada http://eprints.ummi.ac.id/151/2/1.\%20Era\%20Digital\%20da n\%20Tantangannya.pdf p. 1

[8] Wawan Setiawan, "The Digital Age and Its Challenges," Era Digital dan Tantangannya, Seminar Nasional Pendidikan 2017, diakses pada http://eprints.ummi.ac.id/151/2/1.\%20Era\%20Digital\%20da n\%20Tantangannya.pdf p. 1

[9] Jailani, "Democracy System in Indonesia Judging from the Corners of Constitutional Law", SistemDemokrasi di Indonesia DitinjaudariSudutHukumKetataengaraan, JurnalInovatif, Volume VIII Nomor I Januari 2015, p. 140.

[10] Jailani, "Democracy System in Indonesia Judging from the Corners of Constitutional Law", SistemDemokrasi di Indonesia DitinjaudariSudutHukumKetataengaraan, JurnalInovatif, Volume VIII Nomor I Januari 2015, p. 140141.

[11] Jailani, "Democracy System in Indonesia Judging from the Corners of Constitutional Law", SistemDemokrasi di Indonesia DitinjaudariSudutHukumKetataengaraan, JurnalInovatif, Volume VIII Nomor I Januari 2015, p. 141.

[12] [Jailani, "Democracy System in Indonesia Judging from the Corners of Constitutional Law", SistemDemokrasi di Indonesia DitinjaudariSudutHukumKetataengaraan, JurnalInovatif, Volume VIII Nomor I Januari 2015, p. 141142.

[13] Jailani, "Democracy System in Indonesia Judging from the Corners of Constitutional Law", SistemDemokrasi di Indonesia DitinjaudariSudutHukumKetataengaraan, JurnalInovatif, Volume VIII Nomor I Januari 2015, p. 141142.

[14] Jailani, "Democracy System in Indonesia Judging from the Corners of Constitutional Law", SistemDemokrasi di Indonesia DitinjaudariSudutHukumKetataengaraan, JurnalInovatif, Volume VIII Nomor I Januari 2015, p. 143.

[15] Wawan Setiawan, "The Digital Age and Its Challenges,", Era Digital dan Tantangannya, Seminar Nasional Pendidikan 2017, diakses pada http://eprints.ummi.ac.id/151/2/1.\%20Era\%20Digital\%20da n\%20Tantangannya.pdf p. 4. 